\title{
Evolution of the flow of drainage waters in the Oued Righ canal, Algeria
}

\section{Mohammed SAYAH LEMBAREK ${ }^{1) \text { ABCDEF }}$, Boualem REMINI ${ }^{2) A B C D E F} \bowtie$}

\footnotetext{
1) Kasdi Merbah University of Ouargla, Faculty of Technology, Department of Hydraulics, Algeria; e-mail: sayah@yahoo.fr

${ }^{2)}$ Blida 1 University, Faculty of Technology, Department of Water Science and Environmental, Blida 9000, Algeria; e-mail: reminib@yahoo.fr
}

For citation: Sayah Lembarek M., Remini B. 2019. Evolution of the flow of drainage waters in the Oued Righ canal, Algeria. Journal of Water and Land Development. No. 41 (IV-VI) p. 133-138. DOI: 10.2478/jwld-2019-0036.

\begin{abstract}
The channel of the Oued Righ valley plays an important role in draining the drainage waters of the palm groves of 47 oases. This article evaluates and offers a simple relationship calculation of flow of drainage water carried by the channel of Oued Righ. Several work missions were carried out in the Oued Righ Valley during the period: 2010-2018. Investigations and surveys were conducted among the local population. Data and information were collected from the National Hydric Resources Agency (Fr. Agence Nationale des Ressources Hydrauliques) of Touggourt (capital of the Oued Righ Valley). Samples of bottom material and flow velocity measurements were performed at 10 gauging stations located along the canal with a length of $130 \mathrm{~km}$. A simple formula for evaluating the flow rate in the channel has been highlighted. It is a practical quantification tool that will be useful for channel managers. Calculated rate exceeded $5 \mathrm{~m}^{3} \cdot \mathrm{s}^{-1}$ of wastewater and drainage flow into the nature $10 \mathrm{~km}$ before reaching the Chott Merouane; the place of discharge.
\end{abstract}

Key words: canal, drainage water, flow, gauging, Oued Righ

\section{INTRODUCTION}

For centuries, man has learned to live in dry environments like the Sahara. Thanks to his know-how acquired over time, the man has highlighted hydraulic techniques to draw water in the depths of the ground. Rudimentary means, a harsh climate, the man was able to dig wells up to tens of meters. However over time, humans have improved these capture techniques to increase their yield. Thus he designed the foggaras system in the regions of Touat, Gourara and Tidikelt [KoBORI 1982; REMINI 2016; 2017; REMINI et al. 2011; 2012]. Born in ancient Iran for more than 3,000 years [GOBLOT 1963; 1979; HUSSAIN et al. 2008; KAZEMI 2004], the foggara called qanat has completely changed groundwater abstraction patterns. Another genius hydraulic system that was invented in the Saoura Valley. This is khottara; a well with multi-balance made in the oases of the Saoura which makes it possible to increase the flow of drawing [REMINI, REZOUG 2017]. In the Oued Righ valley, it is rather the animal-drawn wells and the rocking wells that have been used. Unlike the other regions of the Sahara, the Oued Righ valley is practically the only region that has a network of canals equipped with a main collector channel to evacuate the drainage water that comes from the return irrigation. Today, this ancestral hydraulic system continues to play an important role in safeguarding the regional environment. Aware of its importance in the economic development of the region, the quantification of the volumes of water transported becomes an essential operation before any project of rehabilitation or maintenance of the main collector.

This is the main objective of this paper which is to implement a simple and practical relationship to evaluate the flow rate at any station. 

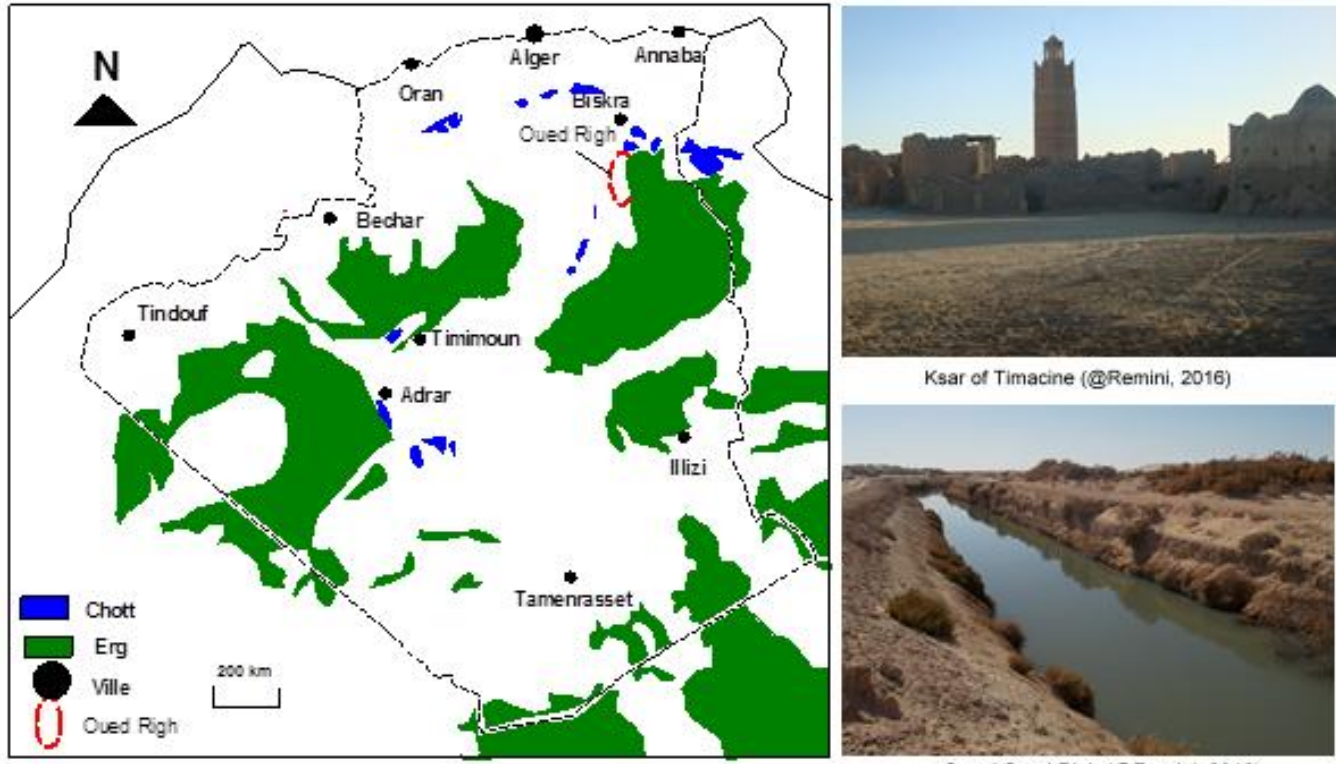

Ksar of Timacine (@Remini, 2016)

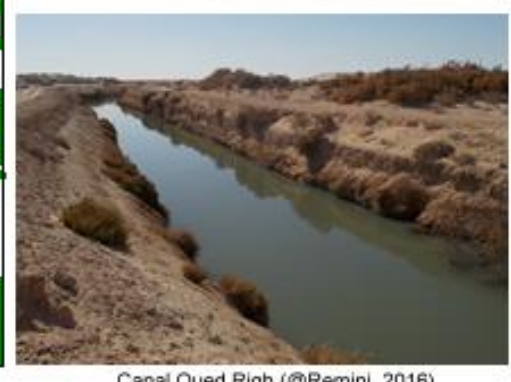

Canal Oued Righ (@Remini, 2016)

Fig. 1. Geographical location of the Oued Righ canal; source: own elaboration

\section{REGION OF STUDY, METHODS AND MATERIALS}

\section{REGION OF STUDY}

An arid region, Oued Righ Valley is a group of oases located on either side of a canal over $130 \mathrm{~km}$ in length. This valley is located between two Wilayas: El Oued and Ouargla. Located $450 \mathrm{~km}$ approximately as the crow flies South-East of Algiers, the climate of the Oued Righ valley is typically Saharan characterized by very low rainfall and high temperatures that can reach $47^{\circ} \mathrm{C}$ (Fig. 1).

The Oued Righ valley is made up of 47 oases of which Touggourt is the capital which is called the city of seven ksour [CHAOUCHE 2008]. Like the Souf valley, the Oued Righ valley exploits the Continental Intercalary aquifer. The Oued Righ valley is fed by 331 boreholes, which generally give a flow of about $9000 \mathrm{dm}^{3} \cdot \mathrm{s}^{-1}$ [BOUZNAD et al. 2016].

\section{MATERIALS AND METHODS}

To achieve our objective, a bibliographic search was started on the premises of the National Hydric Resources Agency of Touggourt (Fr. Agence Nationale des Ressources Hydrauliques - ANRH). Archives and documents dealing with the canal were consulted. All the data on the canal as well as the measurement and granulometry equipment were made available to us by the National Hydric Resources Agency (ANRH) of Touggourt.

\section{- Measuring materials used}

For the flow measurements in the Oued Righ channel, we used the propeller-type windmill: A - OTT C $31 \mathrm{~N}^{\circ}$ 41184, equipped with an F4 counter $N^{\circ} 128542$ (Photo 1, 2). tion:

The calibration of the reel gave us the following rela-

$$
V=0.1300 n+0.019
$$

Where: $V=$ velocity of the current $\left(\mathrm{m} \cdot \mathrm{s}^{-1}\right), n=$ number of propeller revolutions per second.

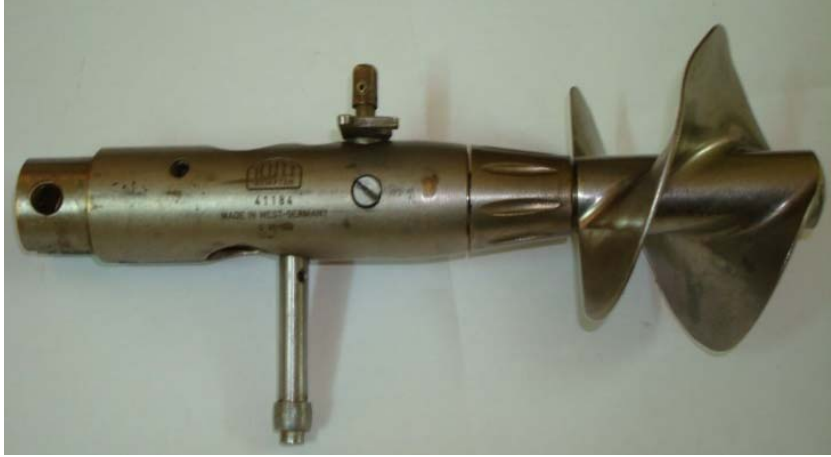

Photo 1. Type of reel used in gauging (phot. M. Sayah Lembarek)

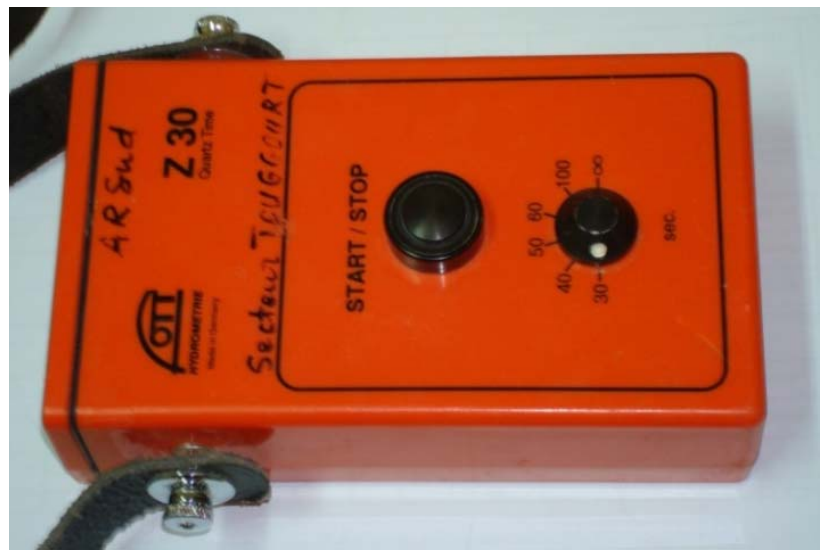

Photo 2. Counter used in gauging (phot. M. Sayah Lembarek)

\section{- Relationships used}

For the determination of velocity, we used Strickler's universal relation [CARLIER 1972]:

$$
V=K \cdot R_{h}^{2 / 3} \cdot I^{1 / 2}
$$

Where: $V=$ average velocity $\left(\mathrm{m} \cdot \mathrm{s}^{-1}\right) ; K=$ roughness coefficient (from Strickler, Meyer-Peter and Müller and Raudkivi); $R_{h}=$ hydraulic radius (taken from gauging); $I=$ slope of the stretch of watercourse (slope of the bottom). 
The roughness coefficient is determined by the empirical formulas: $K=21 \cdot d_{50}{ }^{-1 / 6}$ (Strickler), $K=26 \cdot d_{90}{ }^{-1 / 6}$ (Meyer-Peter and Müller), $K=24 \cdot d_{65}{ }^{-1 / 6}$ (Raudkivi).

\section{- Gauging stations}

For velocity measurements and sampling of bottom material, ten hydrometric stations were taken into account along the channel. These are the stations (Fig. 2): Kerdache $(12 \mathrm{~km})$, Ranou $(24.5 \mathrm{~km})$, Zaouia Labidia $(34.5 \mathrm{~km})$, Bourkhis $(50 \mathrm{~km})$, Sidi Slimane $(55.9 \mathrm{~km})$, Sidi Amrane $(68 \mathrm{~km})$, Zaouiet Riab $(100 \mathrm{~km})$, Tinedla Amont (111.25 $\mathrm{km})$, Tinedla Aval (114 km), Boufeggoussa (125 km).

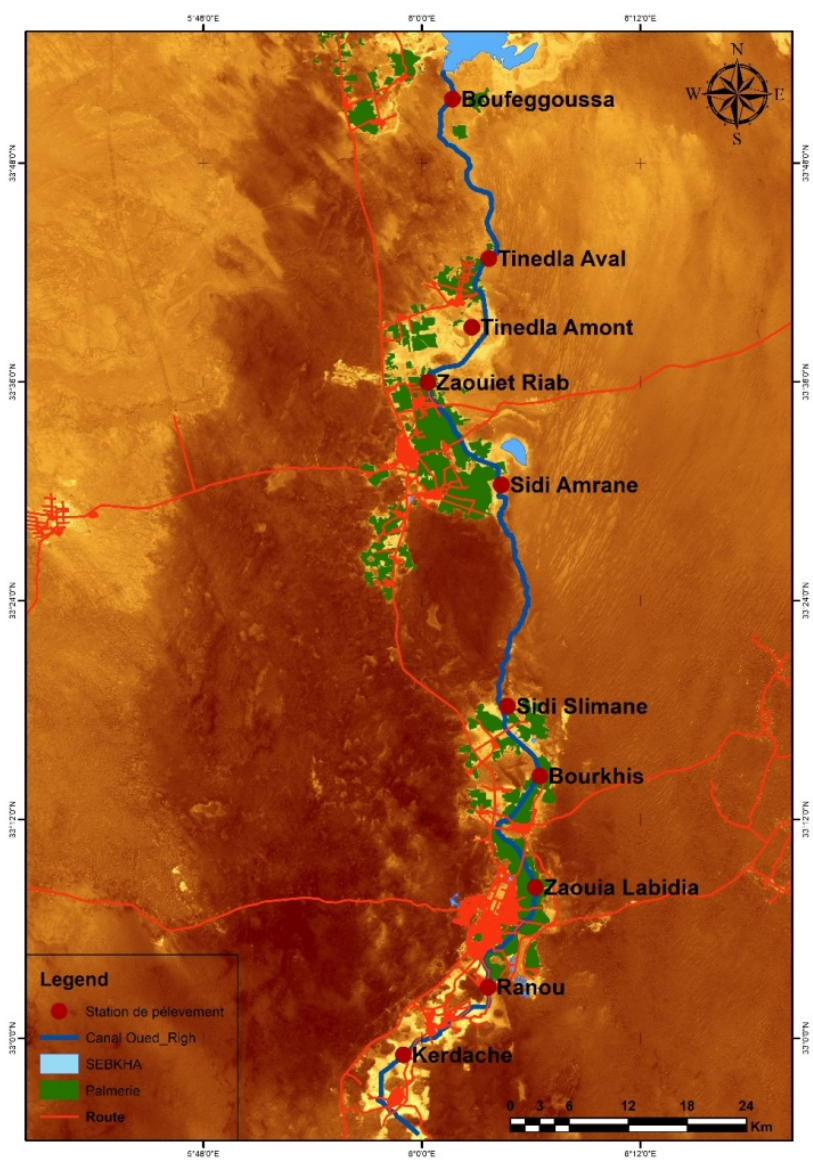

Fig. 2. Hydrometric stations at the canal level (sampling points); source: own elaboration

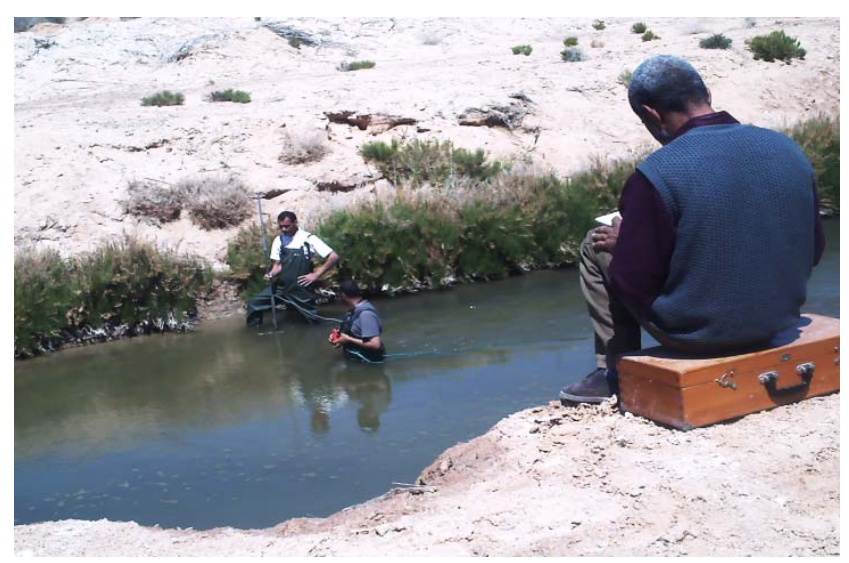

Photo 3. Flow velocity measurements near the left bank of the channel (phot. M. Sayah Lembarek)
For flow measurement, several gauging companions were organized. Three to four person are needed for the success of the measurements. The working conditions in the canal are extremely difficult, especially with the heat and the silt deposits at the bottom of the canal. Two people manipulate the reel and the counter for the third person records the measured values (Photos 3, 4).

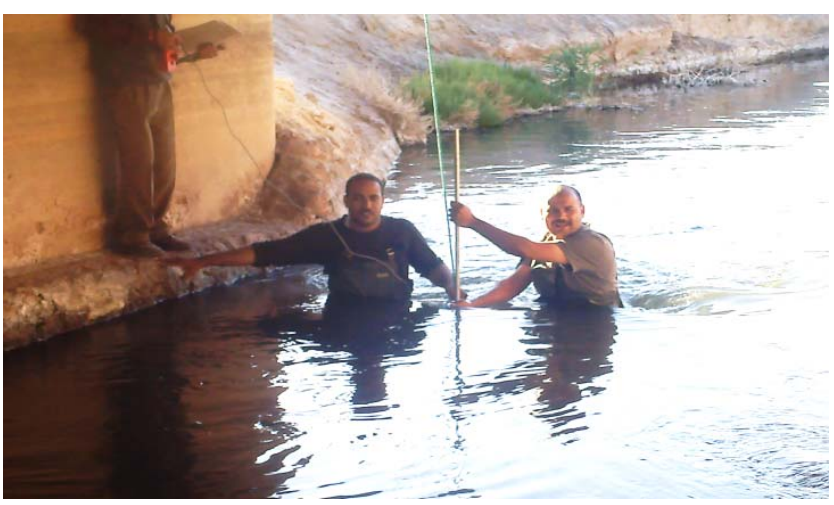

Photo 4. Flow velocity measurements at the centre of the canal (phot. M. Sayah Lembarek)

\section{RESULTS AND DISCUSSIONS}

\section{THE IMPORTANCE OF THE CANAL IN THE OUED RIGH VALLEY}

Designed to evacuate domestic sewage and drainage, the Oued Righ canal with a total length of $132 \mathrm{~km}$ from the oasis of Goug to Merouane Chott; place of rejection (Photo 5). All palm groves (16,000 hectares) and settlements discharge their water (drainage and waste) along this canal running from south to north (Photo 6, 7). Executed in 1910 by the local population, the canal plays an economic and environmental role for the entire region of the Oued Righ valley. Without this structure, the entire region of the Oued Righ valley would be flooded today by the waters of the rising water table. As an example, we must look at the region of Souf, which suffered the consequences of the rise of the water table during the nineties [MILOUDI, REMINI 2016; 2018a, b; REMINI, KECHAD 2011; REMINI, MAINGUET 2003]. Nevertheless, on both sides of the canal, there

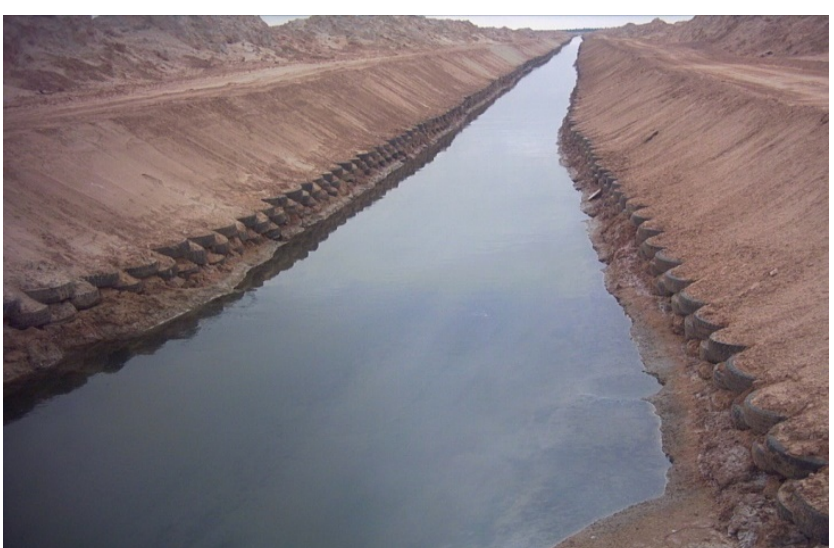

Photo 5. A general view of the magnitude of the channel of Oued Righ (phot. B. Remini) 


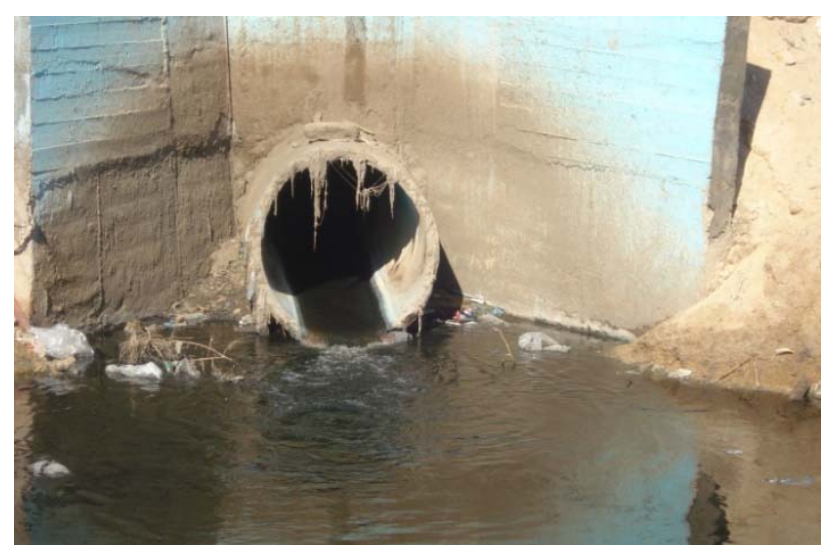

Photo 6. A point of discharge of domestic wastewater in the canal (phot. B. Remini)

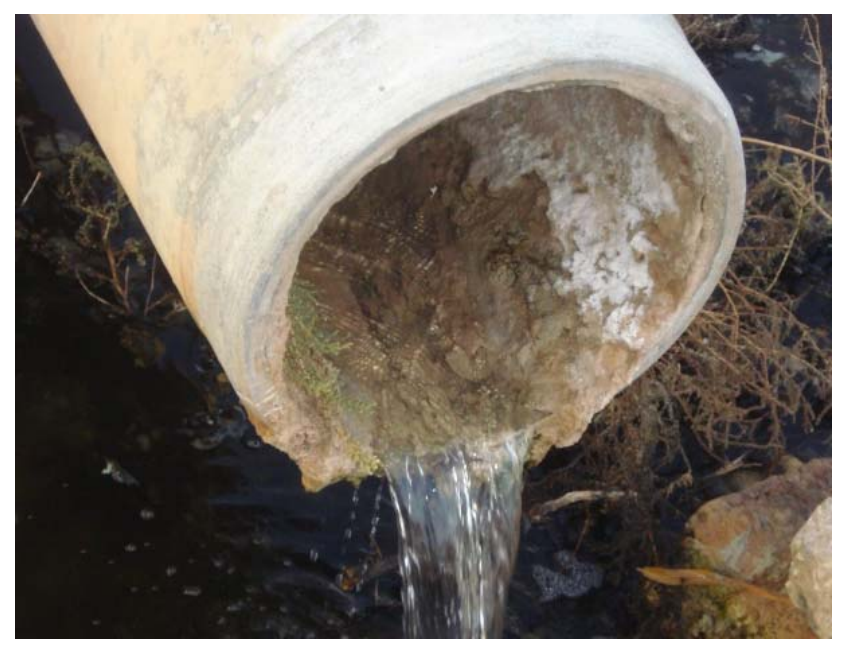

Photo 7. A point of discharge of drainage water in the canal (phot. B. Remini)

are about twenty water-lift sites that have made their appearances [BOUCHHAM et al. 2013].

\section{EVOLUTION OF THE FLOW RATE ALONG THE CANAL}

Due to the discharges of domestic wastewater and all drainage, the flow rate increases along the canal from South to North to Merouane Chott; the place of rejections. Ten gauging stations are located along this channel. The knowledge of this hydraulic parameter is of great use for the managers of this hydraulic structure. The values measured by the reel are shown in Table 1 and shown in Figures 3 and 4. It is interesting to note that the flow obtained at the Tinedela Aval station is $5.32 \mathrm{~m}^{3} \cdot \mathrm{s}^{-1}$; such a high value which testifies to the importance of the discharges of the drainage water coming from the irrigation of the palm groves. However, approaching the last gauging station (Boufegoussa), a station located at the mouth of the Marouane Chott, the flow dropped to $3.24 \mathrm{~m}^{3} \cdot \mathrm{s}^{-1}$, which seems illogical to us. We expected an increase in the flow or the boundary a constant value, since the segment Tinedla-Boufegoussa is a desert region with no agglomeration and the palm grove. This situation forced us to carry out an investigation mission in the region. It turns out that more than $2 \mathrm{~m}^{3} \cdot \mathrm{s}^{-1}$ of water are thrown into the wild,
Table 1. Measured flow values

\begin{tabular}{|l|c|}
\hline \multicolumn{1}{|c|}{ Station } & Flow rate $\left(\mathrm{m}^{3} \cdot \mathrm{s}^{-1}\right)$ \\
\hline Kerdache & 0.13 \\
\hline Ranou & 0.85 \\
\hline Zaouia Labidia & 1.47 \\
\hline Bourkhis & 1.68 \\
\hline Sidi Slimane & 2.10 \\
\hline Sidi Amrane & 1.91 \\
\hline Zaouia Riab & 3.47 \\
\hline Tinedla Amont & 4.22 \\
\hline Tinedla Aval & 5.32 \\
\hline Boufeggoussa & 3.24 \\
\hline
\end{tabular}

Source: own study.

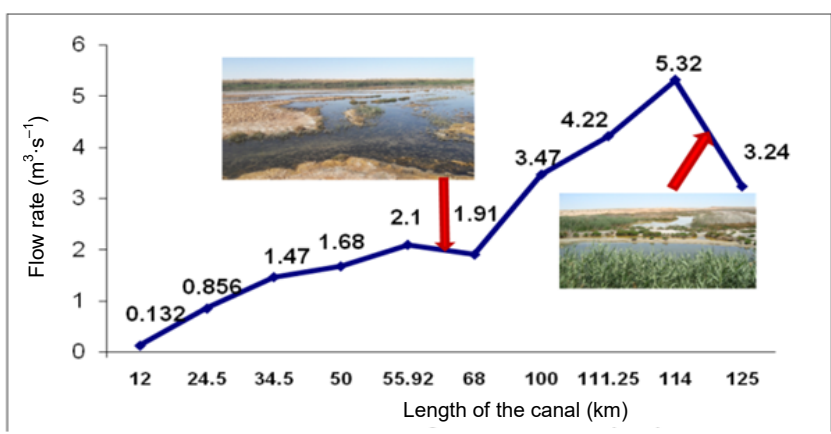

Fig. 3. Variation of the flow according to the length of the channel; source: own elaboration

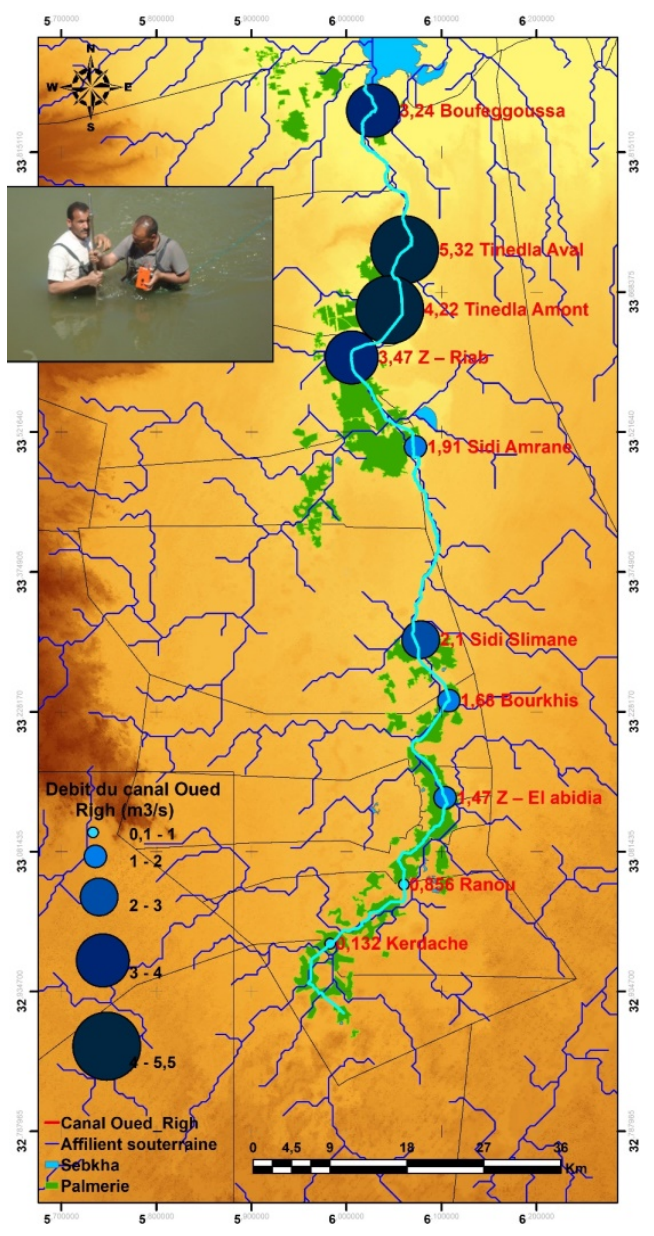

Fig. 4. Map of the Oued Righ canal with the evolution of the flow; source: own elaboration 
forming a large lake because of the deterioration of the canal and the total absence of a skilful bank (Photo 8). In the same situation was observed along the section: Sidi Slimane-Sidi Amrane, the channel is leaking at a rate of more than $0.1 \mathrm{~m}^{3} \cdot \mathrm{s}^{-1}$ of degradation of the channel (Photo 9).

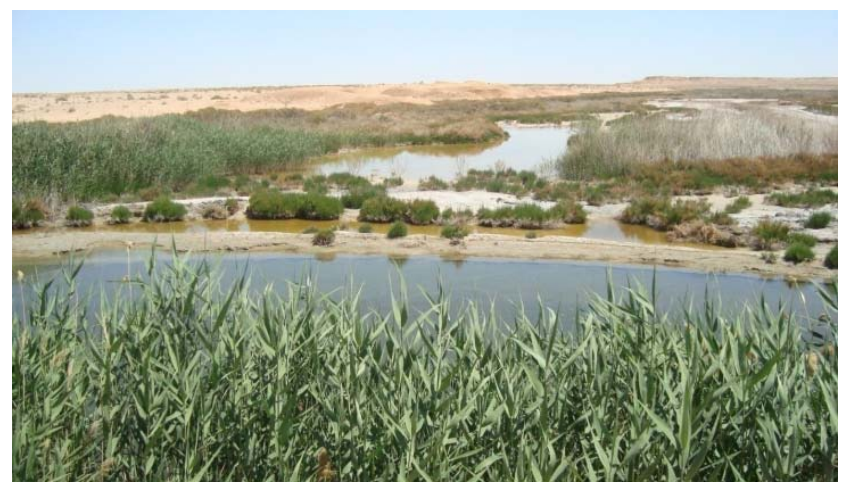

Photo 8. Lake formed by losses of the canal in the section: Tinedla Aval-Boufeggoussa (phot. M. Sayah Lembarek)

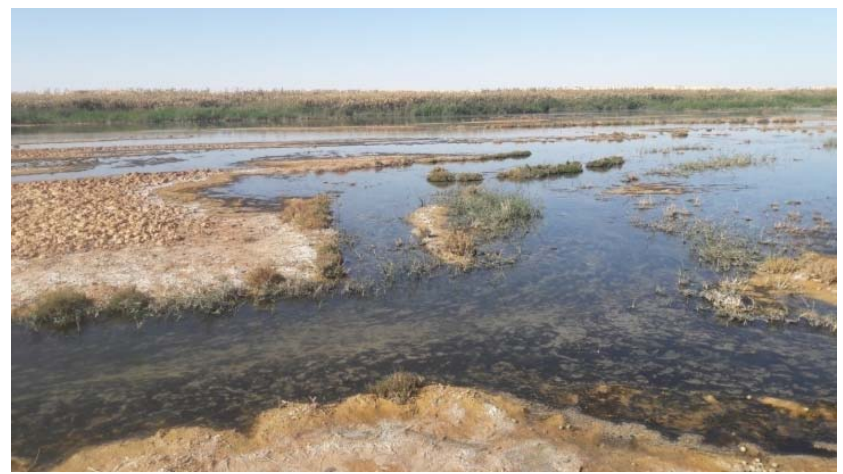

Photo 9. Lake formed by losses of the canal in the section: Sidi Slimane-Sidi Amrane (phot. M. Sayah Lembarek)

\section{IMPLEMENTATION OF A CALCULATION FLOW RELATIONSHIP}

In order to make it easier for channel managers, we have identified a practical relationship that allows us to calculate the flow rate at each station. The relationship is inspired by Strickler. The roughness Strickler's coefficient must take parameters of the channel. Thus a particle size analysis is necessary for the determination of diameters:

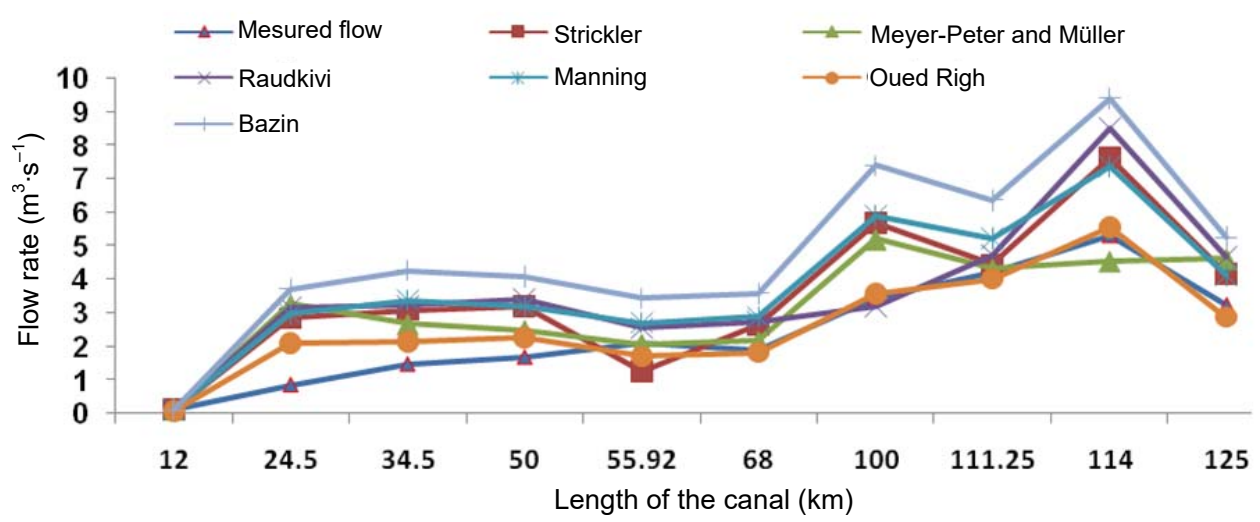

Fig. 5. Validation of the results obtained by the relation of Oued Righ; source: own study $d_{50}, d_{90}$ and $d_{65}$. Samples with a mass of $1 \mathrm{~kg}$ of the bottom material were taken from the sections of 10 gauging stations. Once in the laboratory, the material was put in a tank and dried for 24 hours. Then it was put into a series of vibrating screens of different diameters. The results obtained are shown in Table 2.

Table 2. Diameter value $d_{50}, d_{65}$ and $d_{90}$

\begin{tabular}{|l|c|c|c|}
\hline \multirow{2}{*}{\multicolumn{1}{|c|}{ Station }} & \multicolumn{3}{|c|}{ Diameter } \\
\cline { 2 - 4 } & $d_{50}(\mathrm{~mm})$ & $d_{65}(\mathrm{~mm})$ & $d_{90}(\mathrm{~mm})$ \\
\hline Kerdache & 0.26 & 0.31 & 1.23 \\
\hline Ranou & 0.21 & 0.24 & 0.33 \\
\hline Zaouia Labidia & 0.28 & 0.47 & 2.40 \\
\hline Bourkhis & 0.16 & 0.24 & 2.70 \\
\hline Sidi Slimane & 0.25 & 0.50 & 2.90 \\
\hline Sidi Amrane & 0.28 & 0.48 & 3.30 \\
\hline Zaouiet Riab & 0.20 & 0.17 & 1.20 \\
\hline Tinedla Amont & 0.42 & 0.64 & 1.80 \\
\hline Tinedla Aval & 0.13 & 0.15 & 0.31 \\
\hline Boufeggoussa & 0.15 & 0.17 & 0.29 \\
\hline
\end{tabular}

Source: own elaboration.

The resulting formula derives from Strickler's relationship whose roughness coefficient specific to the Oued Righ canal is $K=16 /\left(d_{65}\right)^{1 / 6}$. In this case, the formula becomes:

$$
Q=\frac{16}{d_{65}^{1 / 6}} R_{h}^{2 / 3} I^{1 / 2} S_{m}
$$

To validate the new formula, we compared the results obtained by our formula with the measured values and calculated by the formulas: Manning-Strickler, Strickler, Meyer-Peter and Müller, Bazin and Raudkivi. The results obtained are shown in Figure 5. It is interesting to note that the results obtained by the Oued Righ formula are similar to the experimental results. Apart from the first three values, where there is a slight shift, the theoretical curve fits well with the experimental curve. For example, there is only a $4 \%$ error in the Tenedela Aval and Sidi Amrane stations.

\section{CONCLUSIONS}

As we mentioned at the beginning of this paper, the Oued Righ Canal plays an important role in the development of the Oued Righ valley. It is thanks to this collector that the domestic wastewater and drainage are evacuated towards the Merouane Chott. The quantification of the volumes of water flowing in this channel becomes a necessity for the managers of the structure. Flow gauges were made with the reel at 10 points along the $130 \mathrm{~km}$ long channel. A flow of more than $5 \mathrm{~m}^{3} \cdot \mathrm{s}^{-1}$ was recorded at the Tinedla Aval station about $10 \mathrm{~km}$ from the outlet (Merouane Chott). However, because of the deg- 
radation of a section of the canal, $2 \mathrm{~m}^{3} \cdot \mathrm{s}^{-1}$ of water is lost in nature by forming a lake of water.

A relationship for flow determination derived from the Strickler formula has been highlighted. Validated with the experimental results, the error committed does not exceed the value of $4 \%$, it is a very encouraging result.

\section{ACKNOWLEDGMENTS}

Without the help of the engineers: Sayah Lembarek Youcef, El Elmi Fodhill and Guegua Salah of the National Hydric Resources Agency of Touggourt, this article will not take place, we would like to thank them warmly. Not to mention the families Sayah and Berrakbia who hosted us during all this period of work.

\section{REFERENCES}

Bouchahm N., Chaib W., Drouiche A., Zahi A., Hamzaoui W., SAlemKour N., FeKraoui F., DJABri L. 2013. Caractérisation et cartographie des sites de remontée dans la région de l'Oued Righ (bas Sahara algerien) [Characterization and mapping of the rise sites in the region of Oued Righ (low Algerian Sahara)]. Algerian Journal of Arid Regions. Special no. p. 76-88.

Bouznad I.E., DerRadjI Z., Nouiri I., KhelfaOui F. 2016. Essay of modelling water resources management of the Oued Righ watershed (Algeria) using the WEAP decision support system. Synthèse. Revue des Sciences et de la Technologie. No. 33 p. $56-71$.

Chaouche B. 2008. Touggourt ou la dynamique d'une ville aux sept ksour [Touggourt or the dynamics of a city with seven ksour]. Sciences and D Technologies. No. 28 p. 9-18.

CARLIER M. 1972. Hydraulique générale et appliquée [General and applied hydraulics]. Paris. Eyrolles pp. 567.

Goвlot H. 1963. In ancient Iran, the techniques of water and great story. Annals Economies Societies Civilizations. Vol. 18. No. 3 p. 499-520.

Goblot H. 1979. Qanats: A technique acquisition of water. Paris. Mouton Editions pp. 231.

Hussain I., ABU-Rizaiza O.S., HabiB M.A., AshfaQ M. 2008. Revitalizing a traditional dryland water supply system, The- karezes in Afghanistan, Iran, Pakistan and the Kingdom of Saudi Arabia. Water International. Vol. 33. No. 3 p. 333-349.

KAZEMI G.A. 2004. Temporal changes in the physical properties and chemical composition of the municipal water supply of shahrood, northeastern Iran. Hydrogeology Journal. No. 12 p. $723-734$.

KOBORI I. 1982. Case studies of foggara oases in the Algerian Sahara and Syria. Tokyo. Tokyo University, Department of Geography. Report. No. 2 pp. 45.

MiLOUDI A.M., REMINI B. 2016. Water potentiality of sustainable management challenges in the Oued Souf Region, south east Algeria [online]. International Journal of Energetica [IJEC]. Vol. 1. No. 1 p. 36-39.

MiLoudi A.M., REMINI B. 2018a. Water resources between conditions of quality and quantity in the Oued Souf region! AIP Conference Proceedings 1968, 020015. DOI 10.1063/ 1.5039174 .

Miloudi A.M., Remini B. 2018b. The ghout of Souf: An original hydroagricultural system. GeoScience Engineering. Vol. 64. No. 3 p. $30-37$.

REMINI B. 2016. The role of the gallery in the functioning of the foggara. Journal of Water and Land Development. No. 29 p. 49-57. DOI 10.1515/jwld-2016-0011.

REMINI B. 2017. Tadmait's foggara: Without energy from the underground water to the surface of the ground. Larhyss Journal. No. 32 p. 301-325.

Remini B., AChour B., Kechad R. 2011. Traditional techniques for increasing the discharge from qanats in Algeria. Irrigation and Drainage Systems. Vol. 25. No. 1 p. 293-306.

Remini B., Achour B., Ouled B.C., BabA A. 2012. The Mzab foggara: An original technique for collecting the water rising. Journal of Water and Land Development. No. 16 p. 49-53.

REMINI B., KECHAD R. 2011. Impact of the water table razing on the degradation of El Oued palm plantation (Algeria). Mechanisms and solutions. Geographia Technica. No. 1 p. $48-56$.

Remini B., Mainguet M. 2003. The upwelling in the region of El Oued (Algeria). Vecteur Environnement. Vol. 37. No. 1 p. $63-67$.

Remini B., Rezoug C. 2017. The khottara of Saoura: A hydraulic heritage in decline. Larhyss Journal. No. 3. p. 273-296.

\section{Mohammed SAYAH LEMBAREK, Boualem REMINI}

\section{Zmiany przepływu wód drenarskich w kanale Oued Righ w Algierii}

\section{STRESZCZENIE}

Kanał w dolinie Oued Righ odgrywa ważną rolę w drenowaniu wód z gajów palmowych w 47 oazach. W pracy dokonano oceny na podstawie prostych obliczeń przepływu wód drenarskich niesionych przez kanał Oued Righ. W latach 2010-2018 wykonano kilka wyjazdów terenowych w rejon doliny. Badaniem i ankietowaniem objęto także lokalną społeczność. Dane i dodatkowe informacje pozyskano z Narodowej Agencji Zasobów Wodnych (fr. Agence Nationale des Ressources Hydrauliques) w Touggourt (miasta stołecznego doliny Oued Righ). W dziesięciu stacjach pomiarowych rozmieszczonych wzdłuż kanału o długości $130 \mathrm{~km}$ pobrano próbki osadu dennego i zmierzono prędkość przepływu. Wyprowadzono prosty wzór do oceny tempa przepływu w kanale. Wzór ten jest praktycznym narzędziem do wykorzystania przez zarządców kanału. Obliczona prędkość przepływu ścieków i wód drenarskich przekraczała $5 \mathrm{~m}^{3} \cdot \mathrm{s}^{-1} \mathrm{~W}$ odległości $10 \mathrm{~km}$ od Chott Merouane, gdzie wody są odprowadzane do środowiska.

Słowa kluczowe: kanat, Oued Righ, przeptyw, punkty pomiarowe, woda drenażowa 